\title{
Türkiye’nin bazı Ortadoğu ülkeleri ile mobilya dış ticareti üzerine bir araştırma
}

\author{
Fatih Tuncay Efe*iD
}

$\ddot{O} z$

1980-1988 yılları arasında İran ile Irak savaşmıștır. 1991'de birinci ve 2003'te ikinci körfez savaşı ve son olarak 2010 yılında başlayan ve "Arap Baharı" denilen karışıklıklar ve çatışmalar yaşanmıştır. Bu gelişmeler Arap ülkelerini olumsuz etkilediği gibi onlarla ticaret yapan komşu ülkeleri de olumsuz etkilemiştir Bu çalışmada bazı Ortadoğu ülkelerinde yaşanan savaş ve karışıklıkların Türkiye'nin bazı mobilya ürünleri dış ticaretine olan etkileri araştırılmıştır. Bu amaçla Türkiye ile Cezayir, Fas, Filistin, Irak, İran, İsrail, Libya, Mısır, Suriye ve Tunus arasındaki bazı mobilya ürünlerinin dış ticaretinin 2008-2018 yılları arasındaki gelişimi incelenmiştir. Çalışmada çeşitli kurum ve kuruluşların istatistik verileri kullanılmıştır. Araştırma sonunda Türkiye'nin bölge ülkeleriyle yaptığg ihracatın 2018 yılında 2008'e göre genel olarak çeşitli oranlarda arttığ ; zaten çok düşük olan ithalatın ise birkaç istisna dışında azaldığı tespit edilmiştir. Özellikle karışıklıkların yaşandığı Fas, Libya, Mısır, Tunus, Cezayir ve Irak'la yapılan diş ticaretin 2015 yılından itibaren hareketlendiği görülmüştür. Ayrıca, 2008-2018 yılları arasında Türkiye ile en az toplam diş ticaret hacmi olan ülkelerin 4.228.000\$ ile Tunus ve 8.538.000\$ ile Filistin olduğu belirlenmiştir. En fazla toplam diş ticaret hacmine sahip ülkelerin ise 2.372.377.000\$ ile Irak ve 715.394.000\$ ile Libya olduğunu belirlenmiştir.

Anahtar kelimeler: Mobilya, Dış ticaret, Ortadoğu

\section{An investigation on the Turkey's foreign trade of furniture products to some Middle East countries}

\begin{abstract}
Iran and Iraq fought with each other between 1980 and 1988 years. The first and the second gulf war in 1991 and 2003 years, respectively, and finally, some conflicts and chaos were happened which named The Arab Spring by 2010. These developments adversely affected Arab countries as well as neighboring countries that trade with them. In this study, the effects of wars and chaos in the Arab countries and the Middle East to Turkey's foreign trade of some furniture products were investigated. For this aim, the developing of foreign trade of some furniture products between Turkey and Algeria, Morocco, Palestine, Iraq, Iran, Israel, Libya, Egypt, Syria and Tunisia investigated in between 2008-2018 years. The statistical data were used of some institutions and organizations. It was determined that Turkey's export was increased with several ratios in 2018 comparatively to 2008 to countries of region; but import that already was very little was decreased some exceptions. The foreign trade with Morocco, Libya, Egypt, Tunisia, Algeria and Iraq which have uncertainties and confusions increasing by 2015 was determined. Moreover, it was determined that two countries which have the least total foreign trade volume with Turkey were Tunisia (4.228.000\$) and Palestine (8.538.000\$), and two countries which have the most total foreign trade volume with Turkey were Iraq (2.372.377.000\$) and Libya (715.394.000\$) between the years of 2008-2018.
\end{abstract}

Keywords: Furniture, Foreign trade, Middle East 


\section{Giriş}

Savaşlar tarih boyunca insanlığı her yönden olumsuz etkilemiştir. Hatta bizzat savaşa dâhil olmayıp savaşan ülkelerle aynı coğrafyada bulunan ülkeler dahi savaşın kötü etkilerini yaşamıştır. Bu etkiler başta ekonomik olmak üzere, siyasi ve sosyal alanlarda da kendini göstermiştir. Ortadoğu coğrafyası ise maalesef binlerce yıldan beri gerek dini sebeplerle gerekse ekonomik sebeplerle birçok savaşı ve karışıklığı yaşamış ve hâlâ yaşamaktadır. Sebebi ne olursa olsun sonuçları ve etkileri tüm toplum üzerinde yıkıcı olmuştur.

Yakın tarihimize baktığımızda 1980-1988 yılları arasında İran ile Irak savaşmış; savaş sadece maddi değil kayıplara değil aynı zamanda binlerce insanın canına mal olmuştur. Her iki ülkede de iç ve dış ticaret felce uğramış, aileler parçalanmış, ülkeler onlarca yıl geriye gitmiştir. Diğer taraftan, 1991 yılındaki birinci ve 2003 yılındaki ikinci körfez savaşları, 2010 yılında başlayan ve adına "Arap Baharı" denilen karışıklıkların yaşandığı Arap ülkelerini etkilediği gibi onlarla dış ticaret yapan komşu ve yakın ülkeleri de olumsuz etkilemiştir.

Ortadoğu'da halkların hak ve özgürlük arayışı ile yaşanan halk hareketleri, 18 Aralık 2010'da Tunus'ta başlayarak iktidar karşıtı kitlesel gösterilerin, 2011 yılı içerisinde Mısır, Libya, Suriye başta olmak üzere Cezayir, Bahreyn, Ürdün, Yemen ve Lübnan gibi Arap dünyasında yer alan ülkeleri içine almıştır ve bu hareketlere uluslararası kamuoyunda "Arap Baharı" adı verilmiştir (Paksoy ve ark., 2015).

Mobilya ürünleri dış ticareti Türkiye için önemli kalemlerden biridir. Doğal olarak yakın ve komşu ülkelerle olan ticaret ulaşım, alım gücü, kültür gibi etkenlerden dolayı daha uzak coğrafyadaki ülkelere göre daha kolay ve sürdürülebilir özelliktedir. Bu anlamda Türkiye'ye komşu ülkeler Irak, Suriye, İran ve Arap coğrafyasının diğer ülkeleri İsrail, Filistin, Lübnan, Fas, Mısır, Libya, Tunus ve Cezayir ile yapılan mobilya ürünleri diş ticareti büyük önem arz etmektedir. Bu ülkelerle Türkiye arasındaki dış ticaret yukarıda bahsedilen savaş ve iç karışıklıklardan olumsuz etkilendi. Ancak savaşların bitmesinden veya bitecek olmasından sonra yeniden yapılanma ve yapılaşmada büyük bir pazar potansiyeli olduğu bir gerçektir.

Geçmiş yıllara ait diş ticaret verileri milli ekonomi planlama ve programlarının yapılmasında gerek ilgili bakanlıklara gerekse özel sektör temsilcilerine yol gösterici olmaktadır. Kaydedilen istatistiksel verilerin analiz edilmesiyle sektörel pazar araştırmaları, kapasite kullanımları, teknolojik yatırımlar, iş gücü geliştirme, Ar-Ge çalışmaları, uluslararası ticari girişimler, vb. faaliyetler optimum duruma getirilmeye çalış1lır. Bu anlamda Ortadoğu ülkeleri ile mobilya ürünleri dış ticaretinin 2008-2018 yılları arasında nasıl bir değişim gösterdiği sonraki yıllar için fikir verecektir.

Yapılan bir araştırmada, Türkiye mobilya endüstrisinin 1997-2003 yılları arasında ürün bazında dış ticaretindeki gelişmeler incelenmiş; mobilya dış ticaretinde ithalatta dalgalanmalar yaşanırken, ihracatta ithalatın tam tersine büyük oranda artış gösterdiği tespit edilmiştir. Bu çalışmada 1997-2003 yılları arasında Türkiye'nin toplam 572490791000 \$'lık bir diş ticaret hacmine sahip olduğu; bunun 351225679 000\$'ını ithalat, 221265112 000\$'ını ise ihracatın oluşturduğunu belirtmişlerdir. Aynı çalışmada 2003 yılı itibarıyla en çok ihracat yapılan ülkelerin sirasıyla Almanya (92.818.000\$), Hollanda (25.681.000\$), Fransa (20.547.000\$), Yunanistan (20.537.000\$) ve İsrail (19.846.000\$) olduğunu ifade etmişlerdir (Efe ve Demirci, 2005).

Yıllardır dış ticaretinin yarıdan fazlasını Avrupa Birliği ile gerçekleştiren Türkiye'nin son dönemlerde bu bölge dışında özellikle Yakın ve Ortadoğu ülkeleri ile de ticari ilişkilerinin arttığı görülmektedir. Bu çalışmada, Türkiye'nin, beş önemli Ortadoğu ticaret partneriyle diş 
ticareti, ticaret yoğunluğu, Grubel-Llyod ve Balassa indeksi gibi çeşitli indeksler hesaplanarak analiz edilmiştir. Türkiye tarafından bakıldığında Türkiye'nin bu beş ülkeyle ticaret yoğunluğunun yüksek olduğu görülmektedir. Bu durum, Türkiye ve bu ülkeler arasında 19992009 döneminde ticari ilişskilerin güçlendiğini göstermektedir. Özellikle Irak ve İran gibi komşu ülkelerle ticaret yoğunluğunun nispeten daha fazla olduğu görülmektedir (Çeştepe, 2012).

Erlat ve Erlat (2012), yaptıkları bir çalışmada 1990-2002 döneminde Türkiye'nin toplam ihracatı içinde, ele alınan Orta Doğu ülkelerinin toplam payının düştüğünü belirtmişlerdir. Bu çalışmaya göre Türkiye'nin ihracatında en yüksek ortalama paya sahip olan ülkeler Suudi Arabistan, İran, İsrail, Mısır ve Suriye olmasına karşın, ihracat payı önemli ölçüde artan ülke İsrail'dir. İthalat içinde Orta Doğu ülkelerinin payına bakıldığında, en yüksek ortalama paya sahip ülkelerin Suudi Arabistan ve İran oldukları görülmektedir.

Yapılan analizlerde Türkiye ve Suriye arasındaki ticaret büyük oranda hammadde ticaretine dayanmaktadır. Şöyle ki; 2000-2009 dönemi Türkiye'nin Suriye'ye yapmış olduğu ortalama ihracatın yaklaşı $\% 75$ 'i, ithalatın ise yaklaşı $\% 85$ 'i hammaddeden oluşmaktadır. SITC-3 (Uluslararası Standart Ticaret Sinıflandırılması-3) sınıflandırılması bazında yapılan analizlerde Türkiye Suriye pazarında 2 numaralı (Akaryakıt hariç yenilmeyen hammaddeler) mal grubu hariç diğer mal gruplarının tamamında karşılaştırmalı üstünlüğe sahip olduğu ve bu mal gruplarında avantajlı konumda olduğu tespit edilmiştir. İkili ticarette özellikle başlıca sınıflara ayrılmış işlenmiş mallar ve makineler ve taşıt araçları mal gruplarında Suriye pazarında Türkiye'nin rekabet gücünün daha yüksek olduğu anlaşılmaktadır (Sandalcılar, 2011).

Mobilya ürünleri 2014 sektör raporuna göre mobilya, ana ve yardımcı unsurlarının yaratmış olduğu 437 milyar \$'lık değer ile dünyadaki en önemli ekonomik sektörlerin başında geldiği belirtilmektedir. Raporda ülke içinde üretilen mobilyanın yarısından fazlası üretilen ülkede satışa sunulurken önemli bir bölümünün de ihracata konu olduğu ifade edilmektedir. Ayrıca raporda dünya çapında mobilya sektörünün 300.000'e yakın kişiyi istihdam ettiği yer almaktadır (MÜSİAD, 2014).

2013 ve 2014 ihracat verilerine göre, Türkiye mobilya sektörünün ihraç pazarları başta Ortadoğu ve Afrika ülkeleridir. Ancak Mısır'la yaşanan politik gerilimden ötürü bu ülke ile mobilya ticareti 2012'nin son aylarından itibaren gerilemeye başlamıştır. Bu noktada bilhassa Ortadoğu ülkelerindeki (Irak, Suriye, Libya vb.) estetik algıya hitap eden mobilyaların üretimine ağırlık verildiği gözlenmektedir. Aynı şekilde, Arap Baharı sonrası istikrar kazanmaya başlayan Kuzey Afrika'nın ve Nijerya, Güney Afrika gibi ülkelerin Türkiye'nin mobilya ihracatı için potansiyel pazarlar olduğu görülmektedir (MÜSİAD, 2014).

Bu çalışmanın amacı, Türkiye ile birtakım çatışma, savaş ve belirsizliklerin yaşandığı Suriye, Irak, İran, İsrail, Filistin, Lübnan, Fas, Tunus, Cezayir ve Misır (Bölge Ülkeleri) arasında 2008-2018 yılları arasındaki mobilya ürünleri dış ticaretinin analizini yapmak ve yorumlamaktır. Önceki çalışmalarda Türkiye'nin genel anlamda ve ağırlıklı olarak AB ülkeleriyle olan mobilya dış ticareti araştırıldığı halde; bu çalışmada bazı Ortadoğu ülkeleriyle yapılan mobilya ürünleri dış ticareti konu edilmiştir. 


\section{Materyal ve Metot}

\subsection{Materyal}

$\mathrm{Bu}$ araştırmada Suriye, Irak, İran, İsrail, Filistin, Lübnan, Fas, Tunus, Cezayir ve Mısır'ın Türkiye ile 2008-2018 yılları arasında yaptıkları mobilya ürünleri dış ticareti istatistikî veriler 1şı̆̆ında incelenmiştir. Bu amaçla resmî kurumların, meslek odaları ve derneklerin, uluslararası kurum ve kuruluşların yapmış oldukları çalışmalar ve daha önce yapılmış akademik çalışmalar incelenmiş ve analiz edilmiştir.

\subsection{Metot}

Araştırmanın konusu, yaşanan savaş ve iç çatışmaların Türkiye ile aynı ve yakın coğrafyada yer alan ülkeler arasındaki mobilya ürünleri dış ticaretini nasıl ve ne derecede etkilediği ve gelecekteki beklentiler üzerine bir analiz yapmaktır. Ayrıca, elde edilen veriler ile Gümrük Tarife İstatistik Pozisyonu (GTIP) 94 faslının çeşitli mobilya ürünlerinin uluslararası ticaretini araştırmaktır. Bu amaçla Türkiye ile Cezayir, Fas, Filistin, Irak, İran, İsrail, Libya, Misır, Suriye, Tunus arasındaki GTIP kodlar1 940130, 940140, 940161, 940330, 940340, 940350 olan bazı mobilya ürünlerinin dış ticaretinin 2008-2018 yılları arasındaki gelişimi incelenmiştir.

\subsubsection{Sektörün Tanımı}

Ticarete konu olan tüm ürünler için iki temel sınıflandırma sistemi kullanılmaktadır. Bunlardan biri detaylı veriler için armonize mal tanımı ve kodlama sistemi (The Harmonized Commodity Description and Coding Systems) kısaca armonize sistem, diğeri ise toplulaştırılmış veriler için standart uluslararası ticari sınıflandırma sistemidir (SITC Rev.3, Standard International Trade Classification).

Kısa anlamda Armonize Sistem, geniş anlamda ise Gümrük Tarife İstatistik Pozisyon Kodları (GTİP) esas alınarak oluşturulan bazı mobilya ürün tanımları aşağıda verilmektedir.

GTİP Kodu-Ürün Tanımları (T.C Ticaret Bakanlığı, 2018)

940130-Yüksekliği ayarlanabilen döner koltuk-sandalyeler

940140-Yatak haline getirilebilen oturma mobilyası (kamp ve bahçe için hariç)

940161-Ahşap iskeletli içi doldurulmuş oturmaya mahsus diğer mobilyalar

940330-Yazıhanelerde kullanılan türde ağaç mobilyalar

940340-Mutfaklarda kullanılan türde ahşap mobilyalar

940350-Yatak odalarında kullanılan türden ahşap mobilyalar.

\section{Bulgular ve Tartışma}

\subsection{Bölge ülkeleri ile Türkiye dış ticaretinin gelişimi}

Yüksekliği ayarlanabilen döner koltuk-sandalyeler (GTIP No: 940130) genellikle ofislerde ve evlerde çalışma odalarında kullanılmakta olup tekstil kaplamalı, metal-plastik konstrüksiyona sahiptir. Bu sandalyeler, ayarlanabilen yüksekliğinin yanı sıra öne arkaya yatma, kolçaklı veya kolçaksız gibi başka özelliklere de sahip olabilmektedir.

Aşağıdaki çizelge ve şekiller 2008-2018 yılları arasında Türkiye ile bölge ülkeleri arasındaki belirlenen mobilya türleri bakımından dış ticaretin nasıl bir değişim gösterdiği konusunda fikir vermektedir. 
Çizelge 1.Yüksekliği ayarlanabilen döner koltuk-sandalyeler (GTIP No: 940130) ihracat1 (ITC, 2019)

\begin{tabular}{lllllllllllll}
\hline Ülke & \multicolumn{1}{l}{ İhracat (1000\$) } \\
\cline { 2 - 5 } & $\mathbf{2 0 0 8}$ & $\mathbf{2 0 0 9}$ & $\mathbf{2 0 1 0}$ & $\mathbf{2 0 1 1}$ & $\mathbf{2 0 1 2}$ & $\mathbf{2 0 1 3}$ & $\mathbf{2 0 1 4}$ & $\mathbf{2 0 1 5}$ & $\mathbf{2 0 1 6}$ & $\mathbf{2 0 1 7}$ & $\mathbf{2 0 1 8}$ & $\begin{array}{l}\text { Değişim } \\
\text { A })\end{array}$ \\
\hline Cezayir & 97 & 215 & 159 & 229 & 132 & 109 & 218 & 417 & 308 & 726 & 479 & 393,81 \\
Fas & 159 & 213 & 269 & 404 & 503 & 982 & 427 & 455 & 386 & 350 & 518 & 225,79 \\
Filistin & 1710 & 1012 & 1022 & 803 & 435 & 749 & 314 & 511 & 338 & 316 & 215 & $-87,43$ \\
Irak & 5147 & 8262 & 9398 & 6976 & 7250 & 7430 & 6339 & 5613 & 3744 & 6604 & 4129 & $-19,78$ \\
İran & 558 & 362 & 408 & 575 & 525 & 1168 & 371 & 418 & 505 & 769 & 1471 & 163,62 \\
İsrail & 700 & 5385 & 6860 & 203 & 3083 & 3693 & 2455 & 823 & 274 & 364 & 1471 & 110,14 \\
Libya & 110 & 36 & 158 & 93 & 273 & 152 & 316 & 584 & 871 & 830 & 793 & 620,91 \\
Misir & 25 & 5 & 0 & 0 & 52 & 0 & 0 & 0 & 1 & 3 & 5 & $-80,00$ \\
Suriye & 248 & 159 & 445 & 85 & 4 & 2 & 6 & 24 & 51 & 259 & 366 & 47,58 \\
Tunus & 20 & 98 & 17 & 12 & 11 & 55 & 24 & 41 & 71 & 15 & 117 & 485,00 \\
\hline
\end{tabular}

Çizelge 1 incelendiğinde, döviz değeri olarak 2008 yılında en fazla ihracatın Irak'a, en az ise Tunus'a yapıldığı; 2018 yılında ise sirasıyla en fazla Irak ve Misır'a yapıldığ görülmektedir. Buna karş1lık 2008'e göre ihracattaki değişim oransal olarak Libya'da, \%620,91, Filistin'de \%-87,43 olarak gerçekleşmiştir. Bu tabloya göre Irak'a fiyatı daha yüksek ürünler ihraç edilirken; Libya'ya miktar olarak daha fazla ürün ihraç edilmiştir. Diğer taraftan Suriye'ye yapılan ihracat 2008 yılından 2013 yılına kadar düzenli olarak düşmüş; 2013 y1lından itibaren düzenli olarak bir artış göstermiş ve \%47,58'lik bir oran yakalanmıştır. Burada dikkate değer olan nokta, Türkiye-Suriye diplomatik ilişkileri 2011 yılından günümüze kadar gittikçe bozulmuş olmasına rağmen bu durumun iki ülke arasındaki ticarete yansımamış olmasıdır.

Çizelge 2.Yüksekliği ayarlanabilen döner koltuk-sandalyeler (GTIP No: 940130) ithalatı (ITC, 2019)

\begin{tabular}{|c|c|c|c|c|c|c|c|c|c|c|c|c|}
\hline \multirow{2}{*}{$\begin{array}{l}\text { Ülke } \\
\text { Adı }\end{array}$} & \multicolumn{11}{|c|}{ İthalat (1000\$) } & \multirow{2}{*}{$\begin{array}{l}\text { Değişim } \\
(\%)\end{array}$} \\
\hline & 2008 & 2009 & 2010 & 2011 & 2012 & 2013 & 2014 & 2015 & 2016 & 2017 & 2018 & \\
\hline Cezayir & 0 & 0 & 0 & 0 & 0 & 0 & 0 & 0 & 0 & 0 & 0 & - \\
\hline Fas & 1 & 0 & 0 & 0 & 0 & 0 & 0 & 0 & 0 & 0 & 0 & $-100,00$ \\
\hline Filistin & 0 & 0 & 0 & 0 & 0 & 0 & 0 & 0 & 0 & 0 & 0 & - \\
\hline Irak & 0 & 0 & 17 & 4 & 1 & 0 & 0 & 0 & 0 & 0 & 1 & 100 \\
\hline İran & 4 & 0 & 0 & 0 & 0 & 0 & 8 & 0 & 0 & 0 & 0 & $-100,00$ \\
\hline İsrail & 0 & 0 & 0 & 0 & 0 & 7 & 0 & 0 & 0 & 0 & 0 & - \\
\hline Libya & 0 & 0 & 0 & 0 & 0 & 0 & 0 & 0 & 0 & 0 & 0 & - \\
\hline Misir & 33 & 34 & 29 & 5 & 0 & 0 & 12 & 0 & 1 & 8 & 4 & $-87,88$ \\
\hline Suriye & 5 & 0 & 25 & 0 & 0 & 0 & 0 & 0 & 0 & 0 & 0 & $-100,00$ \\
\hline Tunus & 0 & 0 & 0 & 0 & 0 & 0 & 0 & 0 & 5 & 0 & 0 & - \\
\hline
\end{tabular}


Çizelge 2'ye göre 940130 GTIP numaralı ürün bakımından Türkiye'nin bölge ülkelerinden ithalatında 2008-2018 yılları arasında genel olarak kayda değer bir değişim göstermediği görülmektedir. Diğer ülkelere göre kayda değer sadece Misır'dan yapılan ithalat \%-87,88 oranında azalmıştır.

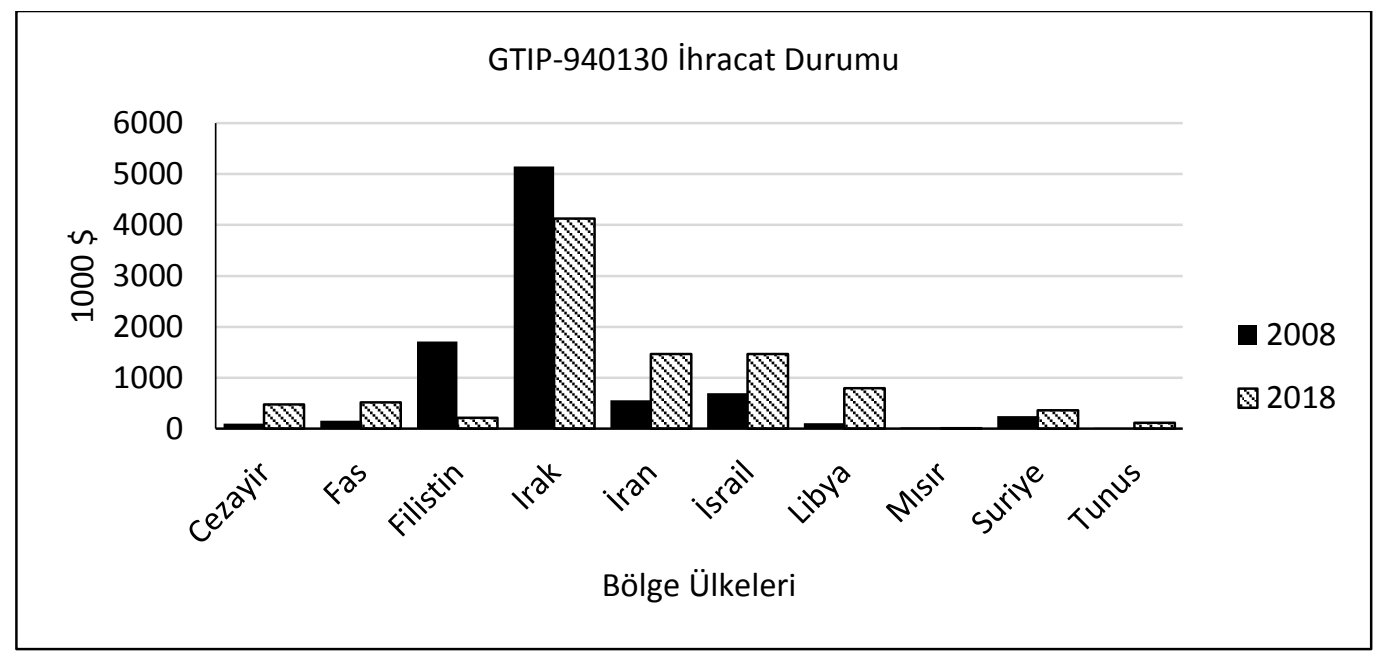

Şekil 1. GTIP-940130 nolu ürün bakımından Türkiye'nin bölge ülkelerine olan ihracatının 2008-2018 yılları arası değişimi (ITC, 2019)

Şekil 1'e göre hem 2008 hem de 2018 'de diğer bölge ülkeleri arasında en yüksek ihracatın Irak'a yapıldığı görülmektedir. Bu durumun oluşmasında hem Irak'ın günümüzde iç karışıklıkları ve belirsizlikleri diğer bölge ülkelerine oranla gidermiş ve ticari faaliyetlerini istikrarı yakalamış olması hem de sahip olduğu petrol gelirinin etkisi olduğu düşünülebilir.

Çizelge 3. Yatak haline getirilebilen oturma mobilyası (kamp ve bahçe için hariç) (GTIP No: 940140) ihracatı (ITC, 2019)

\begin{tabular}{lllllllllllll}
\hline \multirow{2}{*}{ Ülke Adı } & \multicolumn{1}{l}{ İhracat (1000\$) } \\
\cline { 2 - 13 } & $\mathbf{2 0 0 8}$ & $\mathbf{2 0 0 9}$ & $\mathbf{2 0 1 0}$ & $\mathbf{2 0 1 1}$ & $\mathbf{2 0 1 2}$ & $\mathbf{2 0 1 3}$ & $\mathbf{2 0 1 4}$ & $\mathbf{2 0 1 5}$ & $\mathbf{2 0 1 6}$ & $\mathbf{2 0 1 7}$ & $\mathbf{2 0 1 8}$ & $\begin{array}{l}\text { Değişim } \\
\text { (\%) }\end{array}$ \\
\hline Cezayir & 84 & 88 & 181 & 195 & 136 & 206 & 572 & 971 & 620 & 526 & 166 & 97,62 \\
Fas & 348 & 199 & 297 & 416 & 605 & 669 & 901 & 931 & 840 & 1176 & 1255 & 260,63 \\
Filistin & 0 & 0 & 0 & 8 & 0 & 14 & 39 & 0 & 4 & 21 & 2 & 200 \\
Irak & 10802 & 19598 & 22974 & 31110 & 38871 & 37748 & 28012 & 17644 & 17259 & 20212 & 21262 & 96,83 \\
İran & 11711 & 10167 & 11648 & 9338 & 4944 & 646 & 1250 & 1786 & 1695 & 1928 & 861 & $-92,65$ \\
İsrail & 3679 & 2954 & 2656 & 3083 & 2746 & 2923 & 3659 & 3766 & 4427 & 4863 & 5471 & 48,71 \\
Libya & 1288 & 1562 & 1759 & 874 & 5992 & 9048 & 7317 & 3187 & 2064 & 1033 & 1201 & $-6,75$ \\
Misir & 1384 & 1445 & 1743 & 2001 & 2904 & 2785 & 2491 & 3579 & 541 & 148 & 123 & $-91,11$ \\
Suriye & 1022 & 913 & 1738 & 1181 & 17 & 6 & 1 & 49 & 16 & 105 & 112 & $-89,04$ \\
Tunus & 27 & 148 & 22 & 19 & 1 & 3 & 24 & 0 & 5 & 4 & 0 & $-100,00$ \\
\hline
\end{tabular}

Çizelge 3 incelendiğinde 2018 yılı itibarıyla Türkiye ile bölge ülkeleri arasındaki yatak haline getirilebilen oturma mobilyası (kamp ve bahçe için hariç) (GTIP No: 940140) diş ticaretinde en fazla ihracatın 21.262.000\$ ile Irak'a, en az ise Tunus'a yapıldı̆̆ yılları arasındaki değişimin ise \%260,63 ile en fazla Fas'ta, \%-100 ile de Tunus'ta gerçekleştiği görülmektedir. 
Çizelge 4. Yatak haline getirilebilen oturma mobilyası (kamp ve bahçe için hariç) (GTIP No: 940140) ithalatı (ITC, 2019)

\begin{tabular}{|c|c|c|c|c|c|c|c|c|c|c|c|c|}
\hline \multirow{2}{*}{$\begin{array}{l}\text { Ülke } \\
\text { Adı }\end{array}$} & \multicolumn{12}{|c|}{ İthalat (1000\$) } \\
\hline & 2008 & 2009 & 2010 & 2011 & 2012 & 2013 & 2014 & 2015 & 2016 & 2017 & 2018 & $\begin{array}{l}\text { Değişim } \\
(\%)\end{array}$ \\
\hline Cezayir & 0 & 0 & 0 & 0 & 0 & 0 & 0 & 0 & 0 & 0 & 0 & - \\
\hline Fas & 0 & 0 & 0 & 0 & 0 & 0 & 0 & 0 & 0 & 0 & 0 & - \\
\hline Filistin & 0 & 0 & 0 & 0 & 0 & 0 & 0 & 0 & 0 & 0 & 0 & - \\
\hline Irak & 0 & 0 & 0 & 0 & 0 & 24 & 0 & 0 & 0 & 0 & 0 & - \\
\hline İran & 3 & 0 & 0 & 0 & 0 & 0 & 0 & 0 & 3 & 0 & 0 & $-100,00$ \\
\hline İsrail & 0 & 1 & 0 & 0 & 1 & 0 & 0 & 0 & 0 & 0 & 9 & 100,00 \\
\hline Libya & 0 & 0 & 0 & 0 & 0 & 0 & 0 & 0 & 0 & 0 & 0 & - \\
\hline Misir & 0 & 0 & 0 & 0 & 0 & 0 & 1 & 0 & 0 & 0 & 0 & - \\
\hline Suriye & 0 & 0 & 0 & 0 & 0 & 0 & 0 & 0 & 0 & 0 & 0 & - \\
\hline Tunus & 0 & 0 & 0 & 0 & 0 & 0 & 0 & 0 & 0 & 0 & 0 & - \\
\hline
\end{tabular}

Çizelge 4'e göre ise İsrail ve İran hariç diğer bölge ülkelerinden kayda değer bir ithalatın olmadığı; İran'dan yapılan ithalatın 2008'e göre \%-100 azaldığı; İsrail'den yapılan ithalatın ise $\% 100$ arttığ 1 görülmektedir.

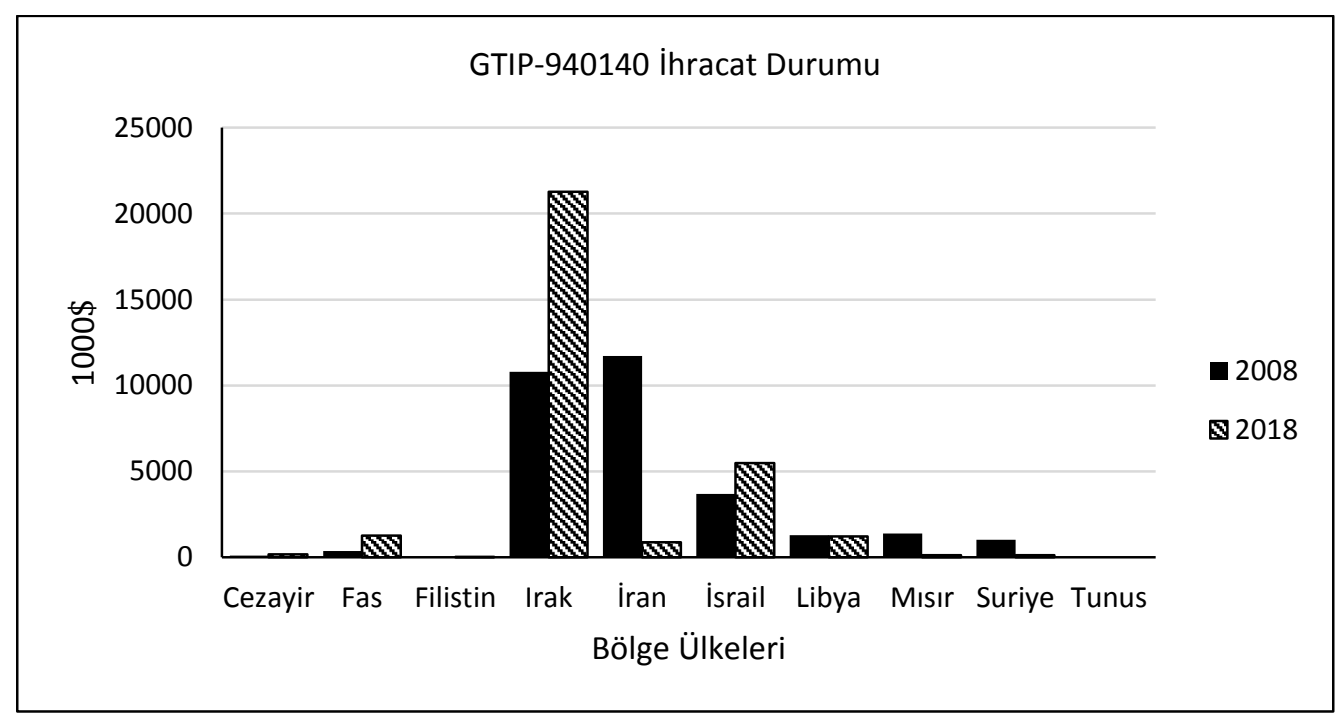

Şekil 2. GTIP-940140 nolu ürün bakımından Türkiye'nin bölge ülkelerine olan ihracatının 2008-2018 yılları arası değişimi (ITC, 2019)

Şekil 2'ye göre gerek 2008'de gerekse 2018'de en fazla ihracat yapılan ilk üç ülke sırasıyla Irak, İran (2018 itibarıyla önemli oranda azalmıştır.) ve İsrail'dir. Libya'da durumun pek değişmediği; Fas'ta biraz arttığı Mısır ve Suriye'de ise önemli oranda azaldığı görülmektedir.

Çizelge 5, Ahşap iskeletli içi doldurulmuş oturmaya mahsus diğer mobilyalar (GTIP No: 940161) ihracatındaki durumu göstermektedir. Bu tabloya göre 2018'de döviz bazında ihracatın en çok arttığı ve azaldığı ülkeler sırasıyla Irak ve Filistin olurken; oransal açıdan en fazla \%4113,56 ile Fas,\%-9,29 ile Suriye ihracatı değişim göstermiştir. 
Çizelge 5. Ahşap iskeletli içi doldurulmuş oturmaya mahsus diğer mobilyalar (GTIP No: 940161) ihracat1 (ITC, 2019)

\begin{tabular}{|c|c|c|c|c|c|c|c|c|c|c|c|c|}
\hline \multirow{2}{*}{$\begin{array}{l}\text { Ülke } \\
\text { Adı }\end{array}$} & \multicolumn{12}{|c|}{ İhracat (1000\$) } \\
\hline & 2008 & 2009 & 2010 & 2011 & 2012 & 2013 & 2014 & 2015 & 2016 & 2017 & 2018 & $\begin{array}{l}\text { Değişimim } \\
(\%)\end{array}$ \\
\hline Cezayir & 55 & 103 & 152 & 169 & 564 & 741 & 1939 & 1849 & 2436 & 1636 & 1562 & 2740,00 \\
\hline Fas & 59 & 29 & 34 & 68 & 101 & 208 & 681 & 1023 & 1038 & 1872 & 2486 & 4113,56 \\
\hline Filistin & 0 & 0 & 0 & 0 & 3 & 0 & 37 & 2 & 2 & 130 & 53 & 100 \\
\hline Irak & 6727 & 10108 & 19354 & 25926 & 38724 & 51692 & 63485 & 60069 & 62783 & 67940 & 72215 & 973,51 \\
\hline İran & 9713 & 7505 & 10818 & 10692 & 8876 & 2869 & 2433 & 2742 & 3132 & 4829 & 3147 & $-67,60$ \\
\hline İsrail & 1496 & 1587 & 1805 & 2203 & 2690 & 2923 & 4458 & 6740 & 10008 & 14165 & 21076 & 1308,82 \\
\hline Libya & 448 & 1646 & 3004 & 826 & 11357 & 19884 & 16940 & 10086 & 5717 & 4639 & 9284 & 1972,32 \\
\hline Misir & 412 & 432 & 508 & 524 & 1750 & 2398 & 3829 & 3596 & 2381 & 850 & 896 & 117,48 \\
\hline Suriye & 452 & 583 & 1402 & 1113 & 57 & 37 & 20 & 80 & 51 & 253 & 410 & $-9,29$ \\
\hline Tunus & 19 & 171 & 2 & 18 & 73 & 50 & 82 & 47 & 25 & 82 & 140 & 636,84 \\
\hline
\end{tabular}

Çizelge 6'da ise Türkiye'nin bölge ülkelerinden yaptığı ithalat durumu görülmektedir. $\mathrm{Bu}$ çizelgeye göre hem döviz değeri bakımından hem de oransal açıdan en fazla ithalat Mısır'dan yapılmış; Suriye'den ise \%100 oranında düşmüştür.

Çizelge 6. Ahşap iskeletli içi doldurulmuş oturmaya mahsus diğer mobilyalar (GTIP No:

940161) ithalatı (ITC, 2019)

\begin{tabular}{|c|c|c|c|c|c|c|c|c|c|c|c|c|}
\hline \multirow{2}{*}{$\begin{array}{l}\text { Ülke } \\
\text { Adı }\end{array}$} & \multicolumn{12}{|c|}{ İthalat (1000\$) } \\
\hline & 2008 & 2009 & 2010 & 2011 & 2012 & 2013 & 2014 & 2015 & 2016 & 2017 & 2018 & $\begin{array}{l}\text { Değişim } \\
(\%)\end{array}$ \\
\hline Cezayir & 0 & 0 & 0 & 0 & 0 & 0 & 0 & 14 & 0 & 0 & 0 & - \\
\hline Fas & 0 & 0 & 0 & 0 & 0 & 0 & 0 & 0 & 17 & 0 & 0 & - \\
\hline Filistin & 0 & 0 & 0 & 0 & 0 & 0 & 0 & 0 & 0 & 0 & 0 & - \\
\hline Irak & 0 & 0 & 0 & 0 & 3 & 0 & 0 & 42 & 0 & 22 & 1 & 100 \\
\hline İran & 207 & 0 & 0 & 0 & 25 & 14 & 22 & 0 & 0 & 0 & 16 & $-92,27$ \\
\hline İsrail & 0 & 0 & 0 & 0 & 0 & 0 & 2 & 0 & 1 & 15 & 0 & - \\
\hline Libya & 0 & 0 & 0 & 0 & 0 & 0 & 0 & 0 & 0 & 0 & 0 & - \\
\hline Misir & 35 & 38 & 57 & 22 & 63 & 113 & 83 & 132 & 382 & 291 & 162 & 362,85 \\
\hline Suriye & 19 & 0 & 0 & 3 & 7 & 0 & 0 & 0 & 74 & 186 & 0 & -100 \\
\hline Tunus & 0 & 0 & 0 & 0 & 0 & 0 & 0 & 0 & 2 & 0 & 0 & - \\
\hline
\end{tabular}

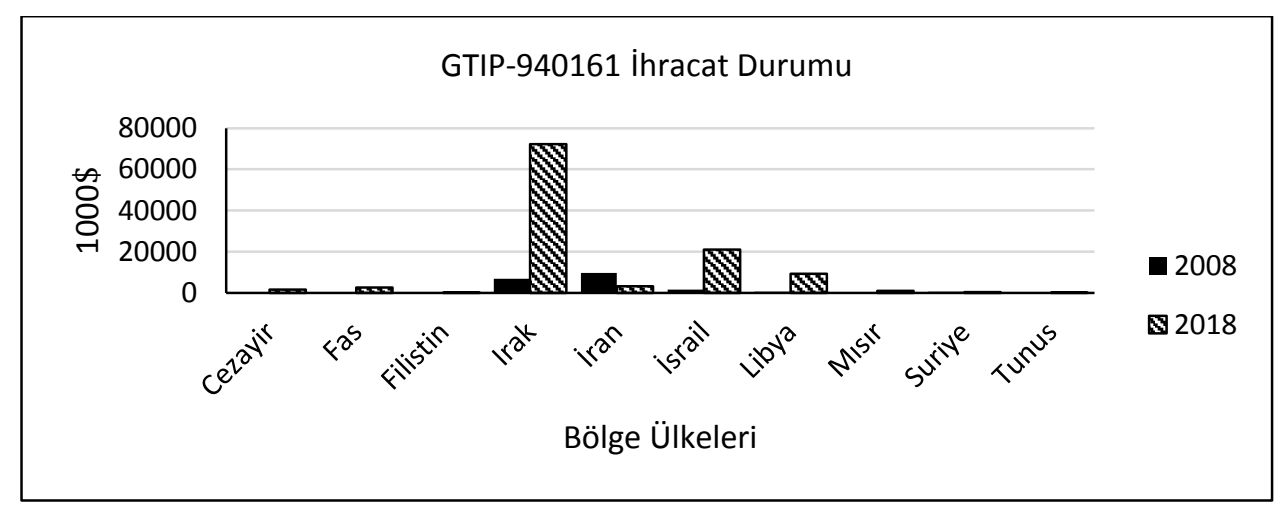

Şekil 3. GTIP-940161 nolu ürün bakımından Türkiye'nin bölge ülkelerine olan ihracatının 2008-2018 yılları arası değişimi (ITC,2019) 
Şekil 3'e bakıldığında 2018 yılı itibarıyla en çok ihracatta göze çarpan ülkelerin sırasıyla Irak, İsrail ve Libya olduğu görülmektedir.

Çizelge 7.Yazıhanelerde kullanılan türde ağaç mobilyalar (GTIP No: 940330) ihracatı (ITC, 2019)

\begin{tabular}{|c|c|c|c|c|c|c|c|c|c|c|c|c|}
\hline \multirow{2}{*}{$\begin{array}{l}\text { Ülke } \\
\text { Adı }\end{array}$} & \multicolumn{12}{|c|}{ İhracat (1000\$) } \\
\hline & 2008 & 2009 & 2010 & 2011 & 2012 & 2013 & 2014 & 2015 & 2016 & 2017 & 2018 & $\begin{array}{l}\text { Değişim } \\
(\%)\end{array}$ \\
\hline Cezayir & 447 & 304 & 163 & 357 & 569 & 414 & 1193 & 911 & 1496 & 1625 & 798 & 78,52 \\
\hline Fas & 238 & 156 & 176 & 233 & 303 & 540 & 721 & 403 & 1084 & 1116 & 1493 & 527,31 \\
\hline Filistin & 36 & 0 & 0 & 0 & 66 & 0 & 0 & 3 & 9 & 26 & 1 & $-97,22$ \\
\hline Irak & 3248 & 3589 & 5022 & 7630 & 13877 & 17017 & 18333 & 8199 & 5431 & 7176 & 8044 & 147,66 \\
\hline İran & 347 & 202 & 406 & 331 & 671 & 1357 & 1461 & 906 & 502 & 383 & 426 & 22,77 \\
\hline İsrail & 1369 & 719 & 673 & 639 & 709 & 813 & 1299 & 1258 & 895 & 1562 & 2007 & 46,60 \\
\hline Libya & 3036 & 5318 & 6384 & 2212 & 10894 & 14066 & 9189 & 3004 & 1658 & 1934 & 6061 & 99,64 \\
\hline Misir & 974 & 1311 & 1015 & 972 & 751 & 1255 & 2046 & 973 & 1101 & 683 & 578 & $-40,66$ \\
\hline Suriye & 646 & 792 & 545 & 237 & 1 & 2 & 256 & 19 & 77 & 97 & 123 & $-80,96$ \\
\hline Tunus & 31 & 34 & 28 & 27 & 21 & 71 & 51 & 204 & 44 & 41 & 46 & 48,39 \\
\hline
\end{tabular}

Çizelge 7'ye göre 2018 yılında yazıhanelerde kullanılan türde ağaç mobilyalar ihracatındaki döviz bazında en fazla artış 8.044.000\$ ile Irak'a, en az ise 1000 \$ ile Filistin'e gerçekleşmiştir. 2008'e göre ihracattaki oransal değişim ise en fazla ve en az sırasıly \%527,31 ile Fas ile \%-97,22 ile Filistin’de görülmüştür.

Çizelge 8. Yazıhanelerde kullanılan türde ağaç mobilyalar (GTIP No: 940330) ithalatı (ITC, 2019)

\begin{tabular}{|c|c|c|c|c|c|c|c|c|c|c|c|c|}
\hline \multirow{2}{*}{$\begin{array}{l}\text { Ülke } \\
\text { Adı }\end{array}$} & \multicolumn{12}{|c|}{ İthalat $(1000 \$)$} \\
\hline & 2008 & 2009 & 2010 & 2011 & 2012 & 2013 & 2014 & 2015 & 2016 & 2017 & 2018 & $\begin{array}{l}\text { Değişim } \\
(\%)\end{array}$ \\
\hline Cezayir & 0 & 0 & 0 & 0 & 0 & 0 & 0 & 0 & 0 & 0 & 0 & - \\
\hline Fas & 0 & 0 & 0 & 0 & 1 & 0 & 0 & 0 & 2 & 0 & 0 & - \\
\hline Filistin & 0 & 0 & 0 & 0 & 0 & 0 & 0 & 0 & 0 & 0 & 0 & - \\
\hline Irak & 0 & 0 & 2 & 9 & 43 & 0 & 0 & 1 & 0 & 0 & 2 & 100 \\
\hline İran & 5 & 0 & 0 & 0 & 0 & 0 & 2 & 0 & 0 & 0 & 0 & $-100,00$ \\
\hline İsrail & 0 & 0 & 0 & 0 & 0 & 0 & 0 & 0 & 1 & 0 & 0 & - \\
\hline Libya & 0 & 0 & 0 & 0 & 0 & 0 & 0 & 0 & 0 & 0 & 0 & - \\
\hline Misir & 4 & 0 & 28 & 7 & 10 & 2 & 8 & 2 & 15 & 2 & 3 & $-25,00$ \\
\hline Suriye & 1 & 3 & 7 & 5 & 0 & 0 & 0 & 0 & 0 & 0 & 0 & $-100,00$ \\
\hline Tunus & 0 & 0 & 0 & 0 & 0 & 1 & 0 & 0 & 0 & 0 & 0 & - \\
\hline
\end{tabular}

2018 yılındaki 940330 GTIP nolu ürünlerin ithalatı bakımından durumu Çizelge 8 göstermektedir. Buna göre, en fazla ithalat 3000\$'lık değerle Misır'dan, en az ise 2000\$'lik değerle Irak'tan yapılmıştır. Diğer taraftan oransal olarak değişim en fazla ve en az sırasıyla \%100 ile Irak ve \%-100 ile İran ile Suriye'de görülmektedir. 


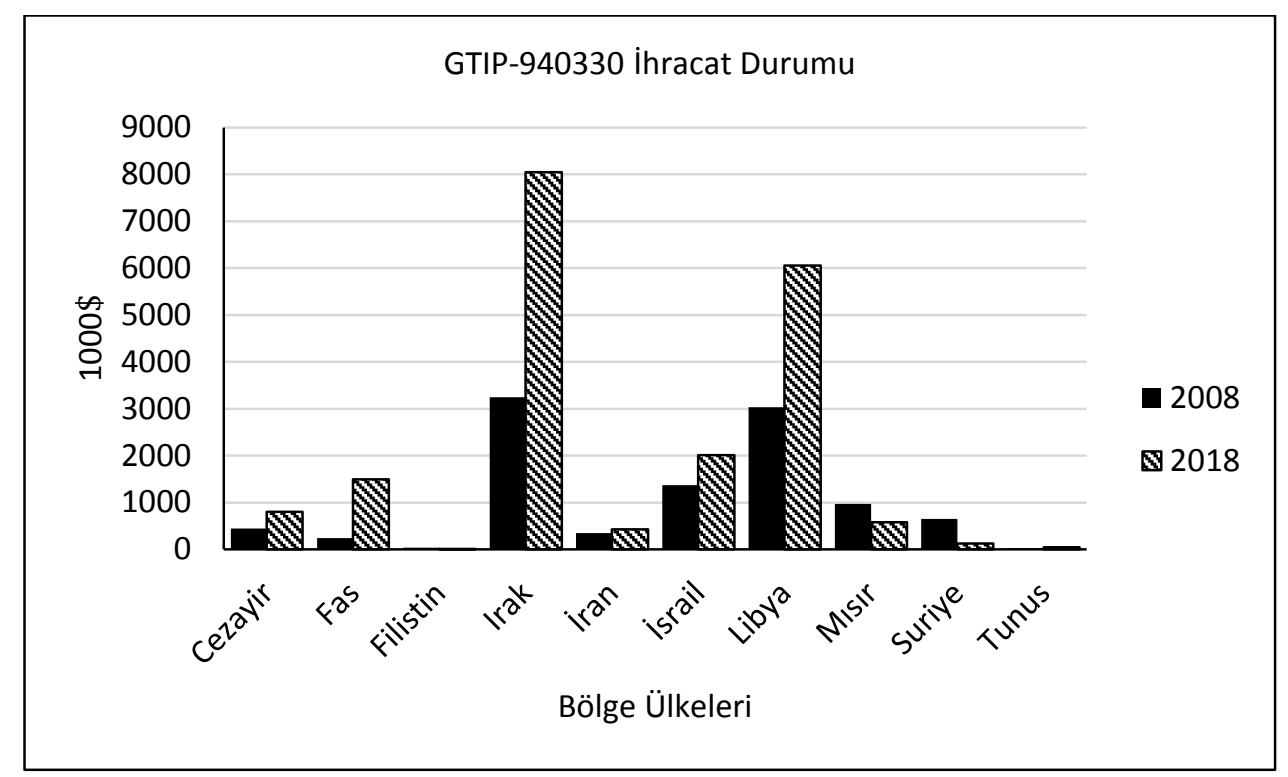

Şekil 4. GTIP-940330 nolu ürün bakımından Türkiye'nin bölge ülkelerine olan ihracatının 2008-2018 yılları arası değişimi (ITC,2019)

Şekil 4'e göre döviz bazında 2018 yılında genel olarak bir artış olduğu; ancak Irak, Libya ve İsrail'e diğerlerinden daha fazla artış olduğu görülmektedir.

Çizelge 9. Mutfak tipi ahşap mobilyaların(GTIP No: 940340) ihracatı (ITC,2019)

\begin{tabular}{|c|c|c|c|c|c|c|c|c|c|c|c|c|}
\hline \multirow{2}{*}{$\begin{array}{l}\text { Ülke } \\
\text { Adı }\end{array}$} & \multicolumn{12}{|c|}{ İhracat (1000\$) } \\
\hline & 2008 & 2009 & 2010 & 2011 & 2012 & 2013 & 2014 & 2015 & 2016 & 2017 & 2018 & $\begin{array}{l}\text { Değişim } \\
(\%)\end{array}$ \\
\hline Cezayir & 113 & 72 & 171 & 135 & 174 & 46 & 72 & 103 & 167 & 261 & 452 & 300,00 \\
\hline Fas & 74 & 31 & 100 & 127 & 245 & 152 & 154 & 204 & 626 & 1336 & 593 & 701,35 \\
\hline Filistin & 0 & 0 & 12 & 0 & 107 & 0 & 0 & 0 & 0 & 0 & 0 & - \\
\hline Irak & 1814 & 2058 & 5116 & 6265 & 8386 & 14086 & 14714 & 12990 & 10147 & 6608 & 4844 & 167,03 \\
\hline İran & 443 & 238 & 443 & 396 & 216 & 457 & 426 & 2309 & 960 & 398 & 737 & 66,37 \\
\hline İsrail & 197 & 218 & 194 & 154 & 216 & 599 & 553 & 116 & 274 & 569 & 1019 & 417,26 \\
\hline Libya & 818 & 1161 & 2210 & 309 & 2165 & 3554 & 2124 & 13489 & 396 & 646 & 674 & $-17,60$ \\
\hline Misir & 90 & 76 & 22 & 69 & 27 & 105 & 93 & 268 & 171 & 80 & 88 & $-2,22$ \\
\hline Suriye & 32 & 27 & 75 & 33 & 0 & 1 & 1 & 2 & 21 & 20 & 58 & 81,25 \\
\hline Tunus & 0 & 40 & 25 & 66 & 85 & 61 & 21 & 57 & 31 & 18 & 27 & 100 \\
\hline
\end{tabular}

Çizelge 9'da Türkiye'nin 2018 yılında bölge ülkelerine yaptığı mutfak tipi ahşap mobilyaların ihracatı gösterilmektedir. Buna göre, en fazla ve en az ihracat döviz bazında 4.844.000\$ ile Irak ve 27.000\$ ile Tunus'a yapılmıştır. İhracattaki oransal değişim ise en fazla ve en az sırasıyla \%701,35 ile Fas ve \%-17,60 ile Libya'da gerçekleşmiştir. 
Çizelge 10. Mutfaklarda kullanılan türde ahşap mobilyalar (GTIP No: 940340) ithalatı (ITC,2019)

\begin{tabular}{|c|c|c|c|c|c|c|c|c|c|c|c|c|}
\hline \multirow{2}{*}{$\begin{array}{l}\text { Ülke } \\
\text { Adı }\end{array}$} & \multicolumn{12}{|c|}{ İthalat (1000\$) } \\
\hline & 2008 & 2009 & 2010 & 2011 & 2012 & 2013 & 2014 & 2015 & 2016 & 2017 & 2018 & $\begin{array}{l}\text { Değişim } \\
(\%)\end{array}$ \\
\hline Cezayir & 0 & 0 & 0 & 0 & 0 & 0 & 0 & 0 & 0 & 0 & 0 & - \\
\hline Fas & 0 & 0 & 0 & 0 & 0 & 0 & 0 & 0 & 0 & 0 & 0 & - \\
\hline Filistin & 0 & 0 & 0 & 0 & 0 & 0 & 0 & 0 & 0 & 0 & 0 & - \\
\hline Irak & 0 & 0 & 0 & 0 & 4 & 2 & 0 & 0 & 11 & 0 & 0 & - \\
\hline İran & 5 & 0 & 0 & 0 & 0 & 0 & 0 & 0 & 0 & 0 & 0 & $-100,00$ \\
\hline İsrail & 0 & 0 & 0 & 0 & 0 & 0 & 0 & 0 & 0 & 0 & 0 & - \\
\hline Libya & 0 & 0 & 0 & 0 & 0 & 0 & 0 & 0 & 0 & 0 & 0 & - \\
\hline Misir & 0 & 0 & 62 & 0 & 0 & 0 & 0 & 3 & 0 & 0 & 0 & - \\
\hline Suriye & 0 & 0 & 12 & 9 & 0 & 0 & 0 & 0 & 0 & 0 & 0 & - \\
\hline Tunus & 0 & 0 & 0 & 0 & 0 & 0 & 0 & 0 & 0 & 0 & 0 & - \\
\hline
\end{tabular}

Bölge ülkeleriyle Türkiye arasındaki ithalat durumunu ise Çizelge 10'da göstermiştir. Çizelgeye göre tek değişim \%-100 ile İran'da olmuş; diğer ülkeler açısından herhangi bir değişim olmamıştır.

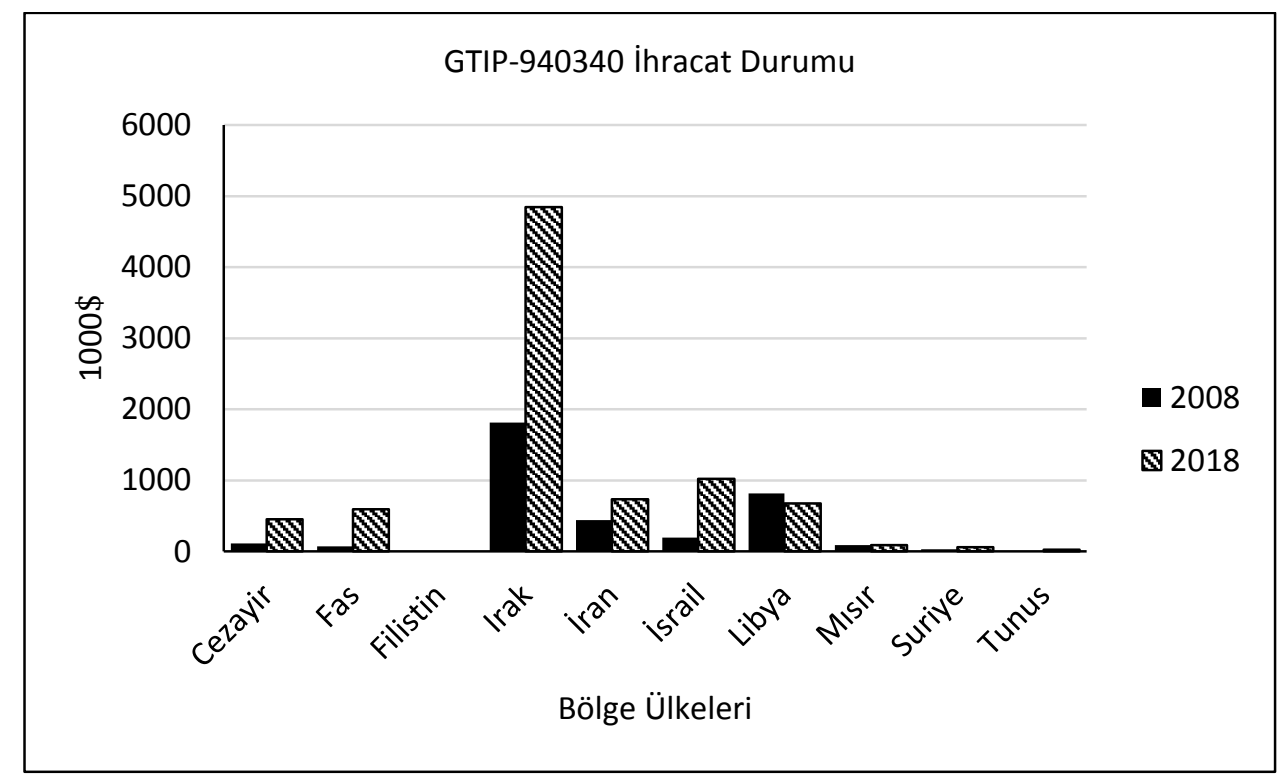

Şekil 5. GTIP-940340 numaralı ürün bakımından Türkiye'nin bölge ülkelerine olan ihracatının 2008-2018 yılları arası değişimi (ITC,2019)

Şekil 5'teki grafiğe göre en yüksek ihracat rakamları hem 2008'de hem de 2018'de Irak'ta oluşmuş; Cezayir, Fas, İran ve İsrail'de ise görece düşük olmakla birlikte artan oranda ihracat gerçekleşmiştir. 
Çizelge 11. Yatak odalarında kullanılan türden ahşap mobilyalar (GTIP No: 940350) ihracatı (ITC, 2019)

\begin{tabular}{llllllllllllll}
\hline $\begin{array}{l}\text { Ülke } \\
\text { Adı }\end{array}$ & \multicolumn{1}{l}{ İhracat (1000\$) } & $\mathbf{2 0 0 8}$ & $\mathbf{2 0 0 9}$ & $\mathbf{2 0 1 0}$ & $\mathbf{2 0 1 1}$ & $\mathbf{2 0 1 2}$ & $\mathbf{2 0 1 3}$ & $\mathbf{2 0 1 4}$ & $\mathbf{2 0 1 5}$ & $\mathbf{2 0 1 6}$ & $\mathbf{2 0 1 7}$ & $\mathbf{2 0 1 8}$ & $\begin{array}{l}\text { Değişim } \\
(\boldsymbol{\%})\end{array}$ \\
\hline Cezayir & 492 & 994 & 2021 & 2706 & 3697 & 4220 & 14261 & 17687 & 20261 & 13366 & 2606 & 429,67 \\
Fas & 1436 & 851 & 903 & 1127 & 1310 & 1087 & 2263 & 2206 & 2030 & 3788 & 5697 & 296,73 \\
Filistin & 215 & 2 & 0 & 0 & 99 & 0 & 214 & 2 & 1 & 0 & 5 & $-97,67$ \\
Irak & 14398 & 26165 & 50237 & 77850 & 119914 & 151183 & 166145 & 169320 & 199325 & 190772 & 206729 & 1335,82 \\
İran & 6497 & 7391 & 9444 & 11965 & 6728 & 3750 & 5037 & 4751 & 4235 & 3231 & 2176 & $-66,51$ \\
İsrail & 1349 & 994 & 1463 & 2785 & 3410 & 3720 & 3670 & 4065 & 8494 & 12923 & 18387 & 1263,01 \\
Libya & 3048 & 4769 & 10035 & 5916 & 69926 & 102641 & 92601 & 60373 & 41748 & 47081 & 62490 & 1950,20 \\
Misir & 1443 & 1343 & 1314 & 1938 & 3099 & 2470 & 3195 & 4701 & 1162 & 418 & 618 & $-57,17$ \\
Suriye & 1843 & 2324 & 3901 & 2311 & 72 & 251 & 279 & 641 & 183 & 207 & 327 & $-82,26$ \\
Tunus & 56 & 49 & 40 & 24 & 30 & 143 & 407 & 351 & 233 & 161 & 254 & 353,57 \\
\hline
\end{tabular}

Türkiye'nin 2008-2018 yılları arası bölge ülkelerine yatak odalarında kullanılan türden ahşap mobilyaların ihracatını gösteren Çizelge 11'de 2018 itibarıyla döviz değeri bakımından en yüksek rakamın 206.729.000\$ ile Irak'a, en düşük rakamın ise 5.000\$ ile Filistin'e ait olduğu görülmektedir. Oransal olarak değișime bakıldığında ise \%1950,20 ile Libya'nın öne çıktığ $;$ \% \%-97,67 ile Filistin'in gerilediği görülmektedir.

Çizelge 12. Yatak odalarında kullanılan türden ahşap mobilyalar (GTIP No: 940350) ithalatı (ITC,2019)

\begin{tabular}{|c|c|c|c|c|c|c|c|c|c|c|c|c|}
\hline \multirow{2}{*}{$\begin{array}{l}\text { Ülke } \\
\text { Adı }\end{array}$} & \multicolumn{12}{|c|}{ İthalat (1000\$) } \\
\hline & 2008 & 2009 & 2010 & 2011 & 2012 & 2013 & 2014 & 2015 & 2016 & 2017 & 2018 & $\begin{array}{l}\text { Değişim } \\
(\%)\end{array}$ \\
\hline Cezayir & 0 & 0 & 0 & 0 & 0 & 0 & 0 & 7 & 0 & 71 & 0 & - \\
\hline Fas & 0 & 0 & 0 & 0 & 0 & 1 & 10 & 0 & 1 & 1 & 0 & - \\
\hline Filistin & 0 & 0 & 0 & 0 & 0 & 0 & 0 & 0 & 0 & 0 & 0 & - \\
\hline Irak & 0 & 0 & 41 & 43 & 19 & 15 & 7 & 0 & 0 & 2 & 22 & 100 \\
\hline İran & 47 & 0 & 0 & 18 & 12 & 2 & 1 & 0 & 0 & 0 & 6 & $-87,23$ \\
\hline İsrail & 0 & 0 & 5 & 0 & 0 & 0 & 5 & 0 & 15 & 56 & 94 & 100 \\
\hline Libya & 0 & 0 & 0 & 41 & 0 & 0 & 0 & 51 & 0 & 0 & 0 & - \\
\hline Misir & 24 & 8 & 50 & 64 & 72 & 96 & 80 & 78 & 78 & 131 & 511 & 2029,17 \\
\hline Suriye & 4 & 6 & 13 & 6 & 0 & 49 & 0 & 0 & 0 & 63 & 0 & $-100,00$ \\
\hline Tunus & 0 & 0 & 0 & 0 & 0 & 0 & 0 & 0 & 0 & 0 & 0 & - \\
\hline
\end{tabular}

Çizelge 12 'de yatak odalarında kullanılan türden ahşap mobilyalar ithalat miktarları verilmiştir. 2018 yılında Türkiye'nin Mısır'dan yaptığı ithalatın \%2029,17 oranında arttı̆ğ; Suriye'den yaptığı ithalatın ise \%100 azaldığ 1 görülmektedir. 


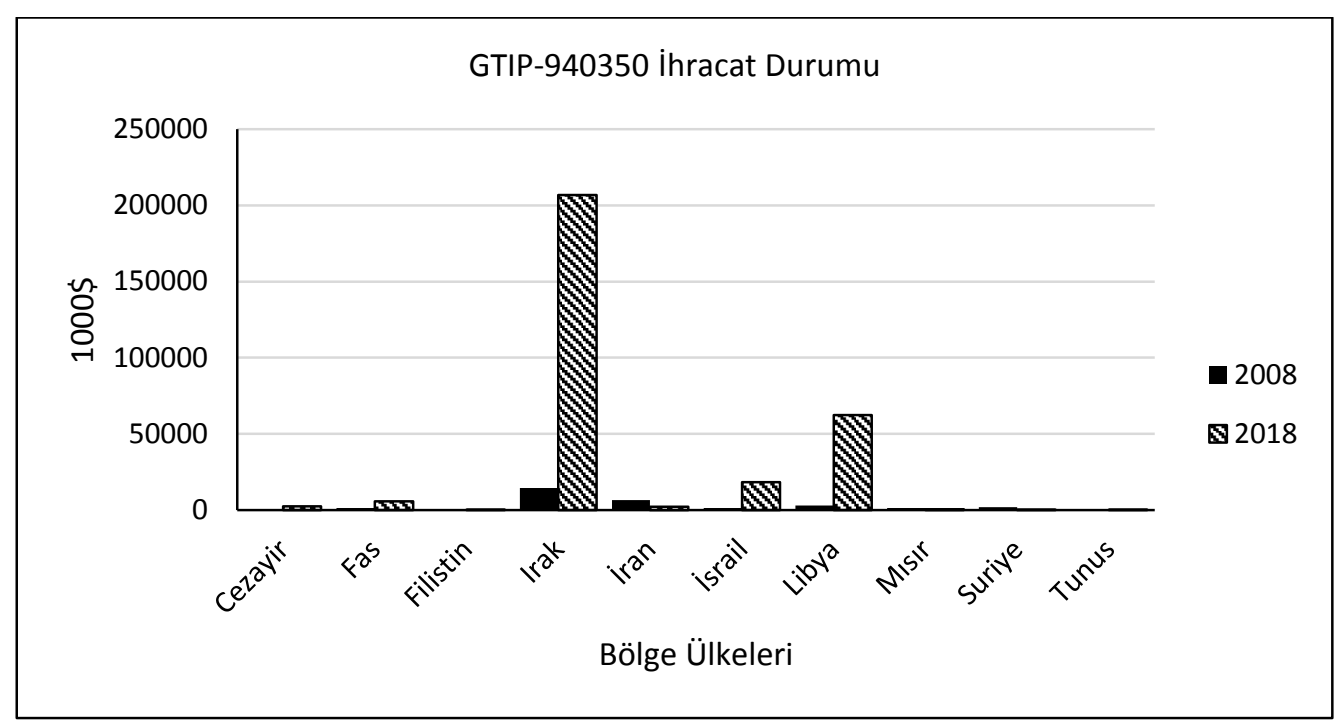

Şekil 6. GTIP-940350 nolu ürün bakımından Türkiye'nin bölge ülkelerine olan ihracatının 2008-2018 yılları arası değişimi (ITC,2019)

Şekil 6'da 2018 yılında bölge ülkelerine yapılan ihracatta döviz değeri bakımından Irak ve Libya'nın bariz şekilde diğerlerinden öne çıktığı görülebilir.

2011 yılında Tunus'ta başlayıp Arap coğrafyasının birçok ülkesine yayılan iç karışıklıklar sonrası hükümetlerde değişiklikler olmuş ve takip eden yıllarda yeni hükümetler kurularak düzen sağlanmaya başlanmıştır. Bu kapsamda Tunus'ta 2015, Cezayir' de 2014, Misır'da 2015, Fas'ta 2017 ve Libya'da 2015'te yeni yönetimler ve hükümetler kurulmuş; Irak'ta kısmen iç karışıklıklar devam etse de ülkenin genelinde asayiş sağlanmıştır. Suriye'de ise henüz iç karışıklıklar bitmemiştir. İran ve İsrail ile zaten eskiye dayanan bir ticaret söz konusu olup; Filistin ile çok sınırlı bir dış ticaret vardır.

Şimdiye kadar diş ticaret hacmi verilen çeşitli mobilya kategorilerindeki özellikle ihracattaki değişime bakıldığında 2015'ten başlayarak2018 yılına kadar birkaç istisna hariç Türkiye'nin Arap baharından etkilenen ülkeler ile yakın coğrafyadaki komşu ülkelerle yapılan dış ticaretin olumlu geliştiği söylenebilir. 2008 yılına göre 2018 y1lı itibarıyla ihracatı olumsuz gelişen ülke ve ürün grupları yüksekliği ayarlanabilen döner koltuk-sandalyelerGTIP No: 940130 için Mısır'da \%-80,00 ve Filistin'de \%-87,43; yatak haline getirilebilen oturma mobilyası (kamp ve bahçe için hariç)-GTIP No: 940140 için Mısır'da \%-91,11, İran'da \%-92,65, Suriye'de \%-89,04 ve Tunus'ta \%-100; ahşap iskeletli içi doldurulmuş oturmaya mahsus diğer mobilyalar-GTIP No: 940161 için İran'da \%-67,60; yazıhanelerde kullanılan türde ağaç mobilyalar-GTIP No: 940330 için Suriye'de \%-80,96, Misır'da \%-40,66 ve Filistin'de \%-97,22; mutfaklarda kullanılan türde ahşap mobilyalar-GTIP No: 940340 için Libya' da \%-17,60 ve Mısır'da \%-2,22; yatak odalarında kullanılan türden ahşap mobilyalarGTIP No: 940350 için Filistin'de \%-97,67, İran'da \%-66,51, Mısır'da \%-57,17 ve Suriye'de \%-82,26 oranında bir değişiklik olmuştur. Diğer tüm ülkelere yapılan ihracat değişen oranlarda artış göstermiştir.

Araştırma konusu ürünlerin zaten az olan ithalatı ise genellikle daha da azalmış; istisna olarak 940140 numaralı ürün için İsrail'de \%100; 940161 numaralı ürün için Misır'da \%362,85; 940350 numaralı ürün için Mısır'da \%2029,17, Irak ve İsrail'de \%100 artmıştır.

MÜSİAD’ın sektör raporundaki (2014) “2013 ve 2014 ihracat verilerinden de anlaşılacağı üzere, Türkiye mobilya sektörünün ihraç pazarları başta Ortadoğu ve Afrika 
ülkeleridir. Ancak Mısır'la yaşanan politik gerilimden ötürü bu ülke ile mobilya ticareti 2012'nin son aylarından itibaren gerilemeye başlamıştır. Bu noktada bilhassa Ortadoğu ülkelerindeki (Irak, Suriye, Libya vb.) estetik algıya hitap eden mobilyaların üretimine ağırlık verildiği gözlenmektedir. Bu bağlamda, hem geleneksel hem modern tonları taşıyan Türk tipi mobilya kavramına derinlik kazandırılması, geleneksel kültürel ve ekonomik hinterlandımız doğrultusunda, Türkiye mobilya sektörünün bu pazarlarda avantaj kazanmasını sağlayacaktır.” ifadesiyle çalışma sonucu elde edilen bulgular ve tespitlerle örtüşmektedir.

Yazıcı (2016)'nın yaptığı bir araştırmada 1995-2014 dönemi içerisinde Türkiye'nin İsrail'e olan ihracatının 11,35 katına, İsrail'den yaptığı ithalatın 16 katına çıktığını; iki ülkenin dış ticaret hacminin ise 13,25 katına çıktığını belirtmiştir. Türkiye'nin İsrail'le 2008-2018 arasında yaptığı mobilya ürünleri dış ticaretindeki gelişmeler bu çalışmada tespit edilen bilgileri teyit etmektedir.

Öncel ve Malik (2015) tarafindan yapılan 2005-15 periyodunu kapsayan analizde Türkiye'nin Tunus, Libya, Mısır, Suriye, Bahreyn ve Yemen'le gerçekleştirdiği ihracatın toplam ihracat içerisindeki payının Arap Baharı öncesinde yükselme eğilimindeyken, Arap baharıyla birlikte hızla azalma trendine girdiğini ve daha sonra tekrar bir toparlanma süreci yaşadığı gözlenmiştir. Ayrıca, ithalat açısından genel bir değerlendirme yapılırsa, her ne kadar ihracat kadar sert hareketler yaşanmamışsa da benzer bir eğilimin ithalatın gelişimi için de söz konusu olduğu belirtilmiştir. Araştırmacılar genel diş ticarete ilişkin tespitlerde bulunmuş olsalar da bu tespitlerin araştırmamızda 2008-2018 yılları arasındaki Türkiye-bölge ülkeleri bazı mobilya ürünleri dış ticaretine ilişsin tespitlere paralel sonuçlar içerdiği görülmektedir.

Öncel ve Akar (2015), çalışmalarında2013 rakamlarıyla değerlendirildiğinde, Türkiye'nin ihracatı açısından ilk beş ülke içerisinde sadece 2. sirada komşusu Irak'ın (\%7,9'luk oranıyla) ve ithalat açısından da sadece 5. sırada komşusu İran'ın (\%4,1'lik oranıyla) yer aldığını; bunun çok az olduğunu ve alınması gereken tedbirlerle bunun artırılabileceğini belirtmişlerdir. Diğer taraftan Suriye ile olan diş ticaretin hacim olarak daraldığ1 dönemlerde (1997-1999 dönemi, 2001-2002 yılları ve 2010-2012 dönemi) iki ülke arasındaki ilişkilerin de genellikle gergin olduğunu ifade etmişlerdir. Bu tespit, çalışmamızda vurgulanan ülkelerin diplomatik ve siyasi ilişkilerinin doğrudan ikili ticaretini de etkilediği yönündeki sonucu desteklemektedir.

Dış ticaret rakamlarındaki değişikliklerde kuşkusuz ülkelerin siyasal ve güvenlikle ilgili belirsizlikleri etkili olmaktadır. Bazen tüketiciler, yeterli güven ortamı oluşuncaya kadar, toplumsal ihtiyaçlarını temin noktasında öncelik sıralamasını değiştirebilmekte, konforla ilgili olanları erteleyebilmektedir. Dolayısıyla ilerleyen yıllarda huzur ve güven ortamı oluştukça şehirlerin, konutların, işyerlerinin yeniden inşası ve teşrifatı ile Türkiye'nin bu ülkelere yapacağı mobilya ve yarı mamul orman ürünleri ihracatının da artacağı tahmin edilmektedir.

\section{Sonuçlar ve Öneriler}

$\mathrm{Bu}$ araştırmada ulaşılan verilere göre araştırmaya konu edilen ülkelere olan mobilya ve yarı mamul orman ürünleri dış ticaretine ilişkin ulaşılan sonuçlar aşağıdaki gibidir:

- Arap baharı hareketlerinden etkilenen ülkelerde yaşanan iç karışıklıklar toplumların ve ülkelerin mobilya kullanım oranları üzerine etkili olmuştur.

- Genel olarak, 2008-2018 y1lları arasında Türkiye'nin bölge ülkeleriyle toplam mobilya dış ticaret hacmi 3.786.726.000\$ olmuştur. Bunun 3.782.210.000\$'1 ihracat ve 4.516.000\$'1 ithalat şeklinde gerçekleşmiştir. 
- 2008-2018 yılları arasında Türkiye ile en az toplam dış ticaret hacmi olan ülkelerin 4.228.000\$ ile Tunus ve 8.538.000\$ ile Filistin olduğu belirlenmiştir. En fazla toplam diş ticaret hacmine sahip ülkelerin ise 2.372.377.000\$ ile Irak ve 715.394.000\$ ile Libya olduğunu belirlenmiştir.

- Türkiye'nin bölge ülkeleriyle geçmişten gelen tarihi, coğrafi ve diplomatik bağlarını koruması ve güçlendirmesi mobilya diş ticareti üzerinde de olumlu etki yapacaktır. Diğer taraftan Türkiye'nin tanıtım ve ikili işbirliği imkânlarını geliştirici tedbirler alması mobilya ihracatını artıracaktır.

\section{Kaynaklar}

Çeştepe, H., (2012), Türkiye'nin seçilmiş Ortadoğu ülkeleriyle ticaretinin analizi. Ekonomik ve Sosyal Araştırmalar Dergisi, 8(2), 23-43.

Efe, H., Demirci S. (2005), Türkiye ve dünya mobilya dış ticareti üzerine bir araştırma, Politeknik Dergisi, 8(2), 179-187.

Erlat, G., Erlat H., (2012), Türkiye'nin orta doğu ülkeleri ile olan ticareti, 1990-2002, Türkiye ekonomi kurumu tartışma metni 2012/26.

ITC (International Trade Center), International trade statistics 2001-2019 http://www.intracen.org/ itc/market-info-tools/trade-statistics/ Son erişim tarihi: 25.11.2019

MÜSİAD (Müstakil Sanayici ve İş adamları Derneği), (2014), Dayanıklı tüketim,mobilya ve orman ürünleri sektör raporu 2014. http://www.musiad.org.tr/tr-tr/musiadkitapligi/arastirma-raporlari, Son erişim tarihi: 21.11.2019

Öncel, A., Malik, A., (2015), The Arab spring and its impact on the foreign trade of Turkey, Bilgi Sosyal Bilimler Dergisi, (31), 17-36.

Öncel, A., Akar, M., (2015), 2000 Sonrası Türkiye-Suriye ilişkilerinin Türkiye dış ticaretine yansımaları, Bilgi Sosyal Bilimler Dergisi, (30), 69-95.

Paksoy, H., M., Koçarslan, H., Kılınç, E., Tunç, A., (2015), Suriyelilerin ekonomik etkisi: Kilis İli Örneği, Birey ve Toplum, 5(1), 143-173

Sandalcılar, A., R., (2011), Türkiye-Suriye diş ticaretinin sektörel analizi, Atatürk Üniversitesi İktisadi ve İdari Bilimler Dergisi, 25(3-4), 2011213.

Türkiye Cumhuriyeti Ticaret Bakanlığı, Mobilya Sektör Raporu, (2018), https://ticaret.gov.tr/data/5b87000813b8761450e18d7b/Mobilya.pdf, Son erişim tarihi: 21.11.2019

Yazıc1, M., (2016), 1995-2014 Döneminde Türkiye- İsrail dış ticareti. Conference: 2nd International Middle East Symposium: State, Non-Stare Actorsand Democracy in The Middle East At: Kırıkkale University, Kırıkkale/ Turkey. 